\title{
Cloning of SjCA gene and its expression analysis on upland cottons
}

\author{
J ingjing Kong, Xuke Lu, Xiaojie Zhao, Zujun Yin, Shuai Wang, Delong Wang, J unjuan Wang, Weili \\ Fan, Wuwei Ye
}

State Key Laboratory of Cotton Biology / Institute of Cotton Research, Chinese Academy of Agricultural Sciences, Anyang, Henan, P. R. China.

Correspondence: Wuwei Ye. Address: Institute of Cotton Research, Chinese Academy of Agricultural Sciences, Anyang, Henan, 455000, China. Email: yew158@163.com

Received: April 18, 2016

DOI : $10.5430 /$ jbei.v2n2p150
Accepted: June 11, $2016 \quad$ Online Published: June 16, 2016

URL: http://dx.doi.org/10.5430/jbei.v2n2p150

\section{Abstract}

Acquisition of salt-tolerant genes from exogenous plants to improve cotton salt resistance has always been a hotspot of research on cotton salt resistance. However, the information regarding the method of conversion of living cotton pollens by portable gene gun technology is still little. Complete sequence information of the Carbonic Anhydrase (CA) gene was obtained from NCBI database, and its full ORF length sequence was cloned by RT-PCR technology. After the construction of pBI121-CA::GFP fusion expression vector, we used cotton pollens from upland cotton varieties Y-2067, ZA-23, and GZ-2, which have weaker autofluorescence, to conduct the research on the transient expression of cotton pollens in vivo via particle bombardment (gene gun technology). The results indicated that green fluorescence enhancement of the three kinds of cotton pollens was realized after the $C A$ gene transformation, meaning that the $C A$ gene expression level was increased. Besides, the salt tolerance germination ability of transgenic T1 seeds was also improved. Our research initially established a transient expression system of cotton pollen in vivo via particle bombardment technology, laying the theoretical foundation for further research of cotton genetic transformation and creation of cotton salt-tolerant germplasm.

\section{Key words}

Transformation, Carbonic Anhydrase (CA), Saccharina japonica, Cotton, Gene gun technology

\section{Introduction}

Due to the continuous land utilization for repeated agricultural activities and the excessive irrigation, the spread and use of saline-alkali soil has become a worldwide ecological problem. Nowadays, the area of global saline-alkali soil is increasing and restricting the world agricultural production. Therefore, the development and exploitation of saline-alkali land has a huge commercial value and important social significance. Planting salt-tolerant crops is one of the accepted ways to make use of saline-alkali soil. As an important pioneer and cash crop, cotton is one of the most appropriate plants for cultivation on saline-alkali soil. Consequently, the improvement of cotton salt tolerance by gene engineering and transgenic technology has been an urgent task and major direction of cotton breeding ${ }^{[1]}$. 
Recently, scientists conducted a large number of researches on the molecular mechanism of plant salt tolerance and found a great number of salt tolerance-related proteins, including enzymes involved in the synthesis of a small organic molecular penetrant, a protective agent, and a series of enzymes participating in salt absorption, translocation, and the regional distribution in cells ${ }^{[2-5]}$. Besides, many salt-tolerant genes were cloned. Carbonic anhydrase (CA, EC 4.2.1.1) containing a zinc atom was cloned and identified to catalyze the reversible conversion between carbon dioxide and bicarbonate radical $\left(\mathrm{CO}_{2}+\mathrm{H}_{2} \mathrm{O} \leftrightarrow \mathrm{HCO}_{3}^{-}\right)^{[6,7]}$, which plays an important role in many biological processes, such as ion exchange, respiration, $\mathrm{pH}$ stabilization, calcification, $\mathrm{CO}_{2}$ capture, and photosynthesis ${ }^{[8-10]}$. Since 1933 , when the $C A$ gene was found in red blood cells, it has also been discovered in all types of mammalian histiocytes. In recent years, scientists have confirmed that $C A$ gene exists in other living organisms, such as higher plants, prokaryotic and eukaryotic algae, bacteria, and other microorganisms ${ }^{[11-13]}$. According to its amino acid sequence and crystal structure, the known $C A$ could be divided into three forms: $\alpha-C A, \beta-C A$, and $\gamma-C A$. However, the sequence similarities between the three $C A$ enzymes were so low that they were assumed to be formed through different evolutionary paths. Among them, $\beta$ - $C A$ exists mainly in the chloroplasts of bacteria, algae, and monocotyledon and dicotyledon plants ${ }^{[14-16]}$.

According to some research findings, there is a relationship between $C A$ response and environmental stress. Previous studies have documented that the change of cotton photosynthetic rate was consistent with the change of $C A$ activity under various conditions (drought, high temperature, and high salinity), showing $C A$ in cotton was a gene related with abiotic stresses ${ }^{[17,18]}$. Previous reports showed that the $C A$ gene expression level and enzyme activity in triticale increased under salt stress, suggesting that $C A$ played a part in the response to salt stress ${ }^{[19]}$. According to the examination findings of $\mathrm{Yu}$ et al., the similar result was also found in rice ${ }^{[20]}$. Fisher et al. cloned the $C A$ gene of strong salt tolerance from Dunaliella salina and found that the expression levels of mRNA and protein were enhanced along with the increase of the concentration of sodium chloride in the nutrient solution ${ }^{[21]}$.

With the advance of research on plant genome, increasing more genes have been included in studies conducted across the world, and the gene transient expression technology has become a fast and effective way for gene expression investigation. Agrobacterium tumefaciens is a soil phytopathogen that could infect plant by the wound sites and causes crown gall disease via delivery of T-DNA from bacterial cells into host plant cells through a bacterial type IV secretion system ${ }^{[22]}$. Although Agrobacterium is a wound-associated pathogen, it is still considered a better way to transfer DNA into diverse host cells or tissues under unwounded conditions ${ }^{[23-25]}$. Compared with the traditional transgenic process, transient expression has several advantages via gene gun method, such as simple operation, short cycle period, and high transformation and expression efficiency. Gene gun is a method in which small metal particles, for example gold powder, wrapped with vector DNA are used to bombard the recipient cells to realize the transformation of DNA, which is also termed as particle bombardment technology. What is more, the stably expressed transgenic plants may cause problems of food chain pollution and gene flow. On the other hand, transgenic expression is an independent process that does not produce hereditable offspring, which contributes to its high bio-safety and reliable results. But the transient expression in cotton pollens was a new, easier and more effective method to study gene expression patterns and obtain transient offspring. Until now, no report has been published concerning the transgenic expression of cotton pollen genes; thus our study provided a new approach to investigate transgenic expression of pollen genes.

The typical, highly salt-tolerant alga, Saccharina japonica, was chosen because it exhibits high homology with the same type of protein from other species, including Dunaliella salina and rice. We speculated that may play a positive role in the response to salt stress. Thus, we tried to transform the $C A$ gene from Saccharina japonica into cotton pollens via the Gene Gun technology to obtain transgenic salt-tolerant plant material. After transforming the cotton pollen, we tested the expression level and established a system of transgenic expression for cotton pollen transformation via particle bombardment, providing the basis of further engineering of salt-tolerant genetic material. 


\section{Materials and methods}

\subsection{Experimental materials}

Gametophyte material from Saccharina japonica was provided by the Ocean University of China, Qingdao, Shandong Province, China. Saccharina japonica is belonged to Laminariales, Phaeophyta, one of the most valuable seaweeds. Saccharina japonica female and male gametophyte clonal lines were preserved as the previous methods in the PES culture medium ${ }^{[26]}$, and the conditions were below: Culture temperature was $17 \pm \pm^{\circ} \mathrm{C}$, light intensity was $40 \mu \mathrm{mol}$ photons $/\left(\mathrm{m}^{2} \bullet \mathrm{s}\right)$, and photoperiod was $16 \mathrm{~h}$ (day) and $8 \mathrm{~h}$ (night). Saccharina japonica female and male gametophytes were collected and crushed with grinder (Philips) into suspension and then centrifuged to collect gametophytes in $100 \mathrm{ml}$ conical flask containing $15 \mathrm{~g}$ fresh gametophytes each. Fresh gametophytes were grinded into superfine powder to extract RNA. The total RNA of Saccharina japonica was extracted using EASY spin Plant RNA Kit (Aidlab), and the first chain of cDNA was completed with TransScript all in one kit (TRANS). First strand cDNA was obtained in a $20 \mu 1$ reaction system, containing $3 \mu \mathrm{l}$ RNA (330 ng/ $\mu \mathrm{l}$ ), $4 \mu \mathrm{l}$ All in one supermix, $1 \mu \mathrm{l}$ gDNA remover and $12 \mu \mathrm{l}$ RNase-free water, and the reaction was completed at $42^{\circ} \mathrm{C}$ for $15 \mathrm{~min}$. At last the tube was subjected to $85^{\circ} \mathrm{C}$ to end the reaction. Products were kept at $-20^{\circ} \mathrm{C}$ for use.

\subsection{Obtaining the complete ORF of CA gene}

The complete information of cDNA from Saccharina japonica was downloaded through searching the existing nucleic acid database in NCBI. To amplify the completed ORF sequence, we designed primers by use of Oligo 6.0 software, CA-F1: 5'-CATCACCATGACTTTCACG-3' and CA-R1: 5'-GTCCACTACTAATGCTCTC-3'. By using cDNA as a template and through the action of LA Taq DNA Polymerase, we obtained the complete ORF sequence. The target bands (TaKaRa, Takara Bio Inc) in the gel were recovered and ligated to the vector pGEM-T Easy (Promega, USA). The ratio of vector and PCR product adapted in the ligation system was 1: 3 . The ligation system was composed with pGEM-T Easy vector $1 \mu \mathrm{l}$, PCR product $3 \mu \mathrm{l}$, T4 DNA ligase $1 \mu \mathrm{l}$ and T4 DNA ligase $2 \times$ quick ligase buffer $5 \mu 1$. After the transformation of competent Escherichia coli cells DH5 $\alpha$ (TaKaRa), the positive clones were selected and sequenced for verification.

\subsection{Bioinformatics analysis}

The sequencing results were analyzed by DNAStar (DNAStar, Madison, WI, USA). The multiple protein sequences were compared by using the DNAMAN software (Lynnon LLC., San Ramon, CA, USA), and the phylogenetic tree of CA was analyzed via MEGA5.0 and built through the neighbor-joining method. Secondary structure prediction was realized by an analysis of the protein function via the DNAStar software.

\subsection{Construction of fluorescent fusion protein expression vector}

As a receptor vector, we used pBI121-GFP, provided by the research group working on cotton early-ripening traits at the Institute of Cotton Research of CAAS, China, and chose two enzyme sites, Xba I and Sma I. The complete ORF sequence was regarded as the target fragment. Infusion primers were designed by the utilization of the online primer design software of the Clontech company.

After amplifying and recovering the target fragments, the fusion protein transient expression vector pBI121-CA::GFP was constructed with in-fusion technology. The primers used were designed with online program http://bioinfo.clontech.com/ infusion. And the forward primer was CA-F2: 5'- CACGGGGGACTC TAGAATGACTT TCACGGCGCACCT-3', and the reverse primer was CA-R2: 5'-AGGGACTG ACCACCCGGGGTAGTGGACGAAGAAGATCT-3'. Ligation system adapted $50 \mu \mathrm{l}$, containing cDNA $0.5 \mu \mathrm{l}$, up/downstream primers $1 \mu \mathrm{l}$ each, dNTP $1 \mu \mathrm{l}$, taq polymerase $1 \mu \mathrm{l}$ and $\mathrm{ddH}_{2} \mathrm{O}$ $45.5 \mu$ l. The competent cells of Escherichia coli DH5 $\alpha$ were used to perform transformation before further sequencing and identification of the positive clone results. 


\subsection{Green auto-fluorescence detection of the cotton pollen}

Twenty-six cotton varieties (were identified by our laboratory for many years) were chosen, and their pollens were collected. Green auto-fluorescence detection was performed by confocal laser scanning microscopy (FV1000, Olympus, Japan) at a wavelength of $488 \mathrm{~nm}$ (excitation light was green at the wavelength of $488 \mathrm{~nm}$ ). We only selected cotton varieties with weak green auto-fluorescence from the 26 cotton varieties for the interference of strong green auto-fluorescence.

\subsection{Transformation of the cotton pollen via in vivo particle bombardment technology}

Gold powder ( $1 \mu \mathrm{m}$ diameter of the particles) was washed with $70 \%$ ethanol and sterile purified water. Gold powder suspension liquid was prepared by adding sterile purified water. First, $30 \mathrm{mg}$ was added into a $1.5 \mathrm{ml}$ tube containing $1 \mathrm{ml}$ $70 \%$ ethanol, shaking for $5 \mathrm{~min}$; then centrifuged for $30 \mathrm{~s}$ at 12,000 rpm after standing for $15 \mathrm{~min}$ and discarded the

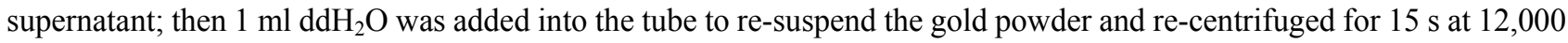
rpm and discarded the supernatant. Ethanol and $\mathrm{ddH}_{2} \mathrm{O}$ were used to re-cycle the steps above. At last, gold power washed

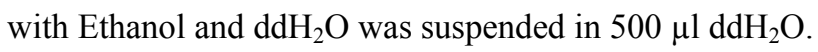

Aliquots of $100 \mu 1$ gold powder suspension liquid were subjected to shaking after adding the plasmid pBI121-CA::GFP. Meanwhile, pre-cooling $40 \mu \mathrm{l} 0.1 \mathrm{~mol} \cdot \mathrm{l}^{-1}$ spermidine and $100 \mu \mathrm{l} 2.5 \mathrm{~mol} \cdot \mathrm{l}^{-1} \mathrm{CaCl}_{2}$ were added into the suspension liquid, dropwise. After mixing and centrifugation, the supernatant was discarded. Then $200 \mu \mathrm{l}$ ethanol was used to wash and resuspend the mixture of plasmid and gold powder. The products were saved at $-20^{\circ} \mathrm{C}$ for further use.

The gene delivery tool GDS-80 (Wealtec corp) was utilized to bombard the cotton pollens. The pressure of the helium tank was adjusted to $1,350 \mathrm{psi}$, and $10 \mu \mathrm{l}$ of particle suspension wrapped in DNA was added into the center of GDS-80 before the bombardment. The pollens were collected the day before and stored at room temperature for the bombardment. Finally, the pollens bombarded were stored overnight without light at $25^{\circ} \mathrm{C}$. Then a brush was used to dip in the pollens bombarded and dropped the pollens on a new sterile glass slide. Then a drop of $\mathrm{ddH}_{2} \mathrm{O}$ was added on the pollens to make a temporary slide to be observed. The gene transient expression was observed with Laser Confocal Scanning Microscope (FV1000) at a wavelength of $488 \mathrm{~nm}$.

\section{Results}

\subsection{The cloning of CA gene from Saccharina japonica and its bioinformatics analysis}

By PCR amplification, complete $C A$ gene ORF was obtained: a product with a size of $873 \mathrm{bp}$, which encoded 290 amino acids (see Figure 1A). Another 10 species were chosen for a multiple sequence comparison. By performing BLAST in NCBI for $C A$ gene-coded amino acid sequence, homology with the proteins of other species was observed. Among them, the similarity between $C A$ and Dunaliella salina, Oryza sativa Japonica, Sinorhizobium meliloti, and Oncorhynchus mykiss reached $89 \%, 79 \%, 78 \%$, and $70 \%$, respectively. The ten pre-selected representative species for a multiple sequence comparison were as follows: Chlorella sorokiniana (BAA28217), Gossypium hirsutum (AAM22683), Sinorhizobium meliloti (NP_435267), Dunaliella salina (AAO83593), Oryza sativa Japonica Group (BAD29283), Pasteurella multocida (AAK03989), Human Carbonic Anhydrase Iv (pdb|1ZNC|A), Oncorhynchus mykiss (AAR99330), Tetraodon nigroviridis (CAG08972), and Gallus gallus (XP_415893) (see Figure 1B). An evolutionary tree was constructed to analyze the evolutionary relationship of $C A$ gene in different species (see Figure 1C). The sequence comparison results indicated high conservation with other species and a low similarity with the cotton sequence, meaning 
that the $C A$ proteins of cotton and Saccharina japonica belonged to different kinds. The phylogenetic tree findings showed that the $C A$ of Saccharina japonica had a short evolutionary distance from the $C A$ of Dunaliella salina, meaning that a closer genetic relationship was existent. The two $C A$ s belonged to one type, and we speculated that $C A$ may play a vital role in the salt stress environment. However, the $C A$ of Saccharina japonica and the $C A$ of upland cotton had a long evolutionary distance, and we assumed that they pertain to different kinds. We imported the $C A$ gene sequence of a gametocyte from Saccharina japonica into the Protean (DNAStar, Madison, WI, USA) in DNAStar for a secondary structure prediction and the results revealed that the structure included $\alpha$-helices, $\beta$-sheets, torsion angle, and a random coil. The prediction result of $C A$ gene location with online program PSORT (http://psort.hgc.jp/form.html) showed that the gene was located on plasma membrane or endoplasmic reticulum (membrane), so we speculated this protein was a membrane protein. Besides, online program ProtScale (http://web.expasy.org/protscale/) was used to predict the hydrophilic-hydrophobic property of the $C A$ protein and the result indicated this protein was a hydropathicity protein. We also conducted the signal-protein prediction (see Figure $2 \mathrm{~A}$ ), and the results indicated that there was a typical signalprotein digestion site at 20-21 (Gly-Val), which site would be important for the function of $C A$ gene.

(A)

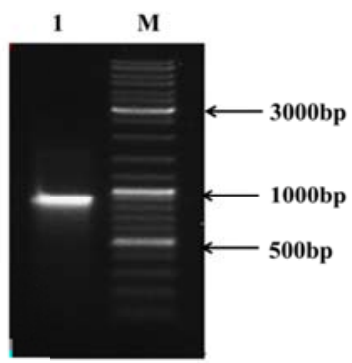

(C)

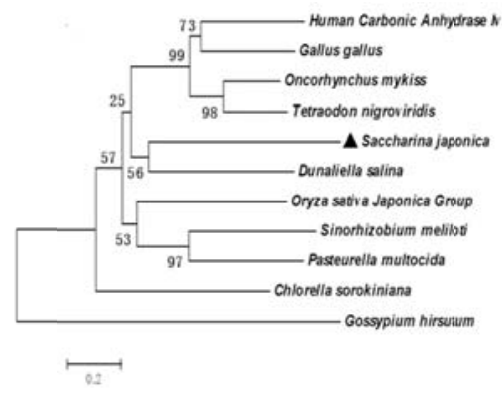

(B)

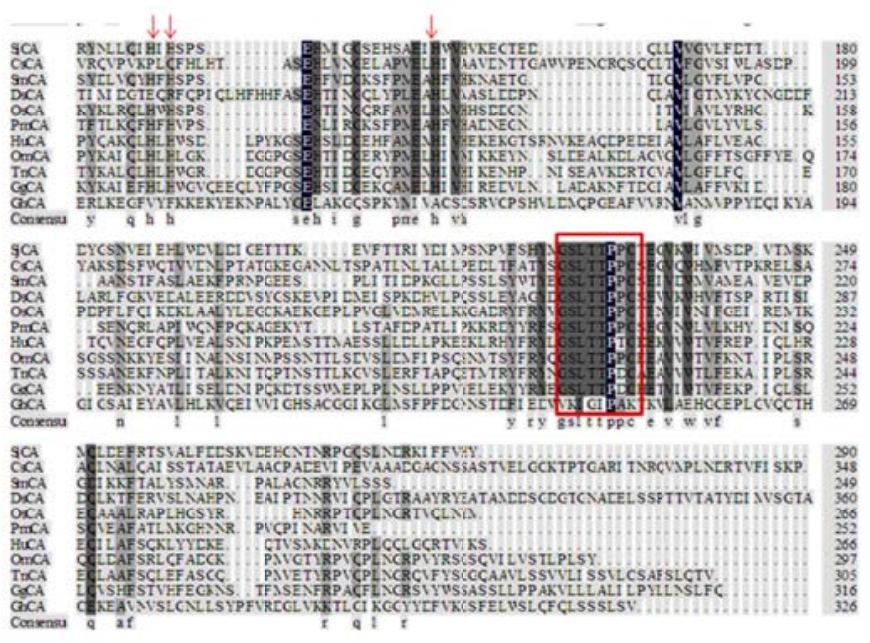

Figure 1. Amplification, multiple alignment and phylogenetic analysis of $C A$ gene. (A) Amplification of $C A$ gene ORF. 1: ORF frame gene PCR product; M: DNA marker SM. (B) Alignment of the deduced amino acid sequence of $S j C A$ and that from other species. Identical residues are shaded in black and similar residues in grey, the box indicates the conservative domain and the red arrow shows the Zn-binding sites. (C) Phylogenetic tree of putative CA gene from Saccharina japonica and other spices.

\subsection{The construction of the expression vector of fluorescent fusion protein}

We inserted the $C A$ gene into the plant expression vector pBI121-GFP to construct a fusion protein expression vector. After conversion to the competent cells of Escherichia coli DH5 $\alpha$, the positive clone was screened by kanamycin and was selected by colony PCR identification and sequencing. The results of the sequence comparison and further digestion insertion were correct, demonstrating that the expression vector was constructed successfully. We named the constructed expression vector $\mathrm{pBI} 121-\mathrm{CA}:$ GFP whose detailed description was displayed in Figure 2B. 

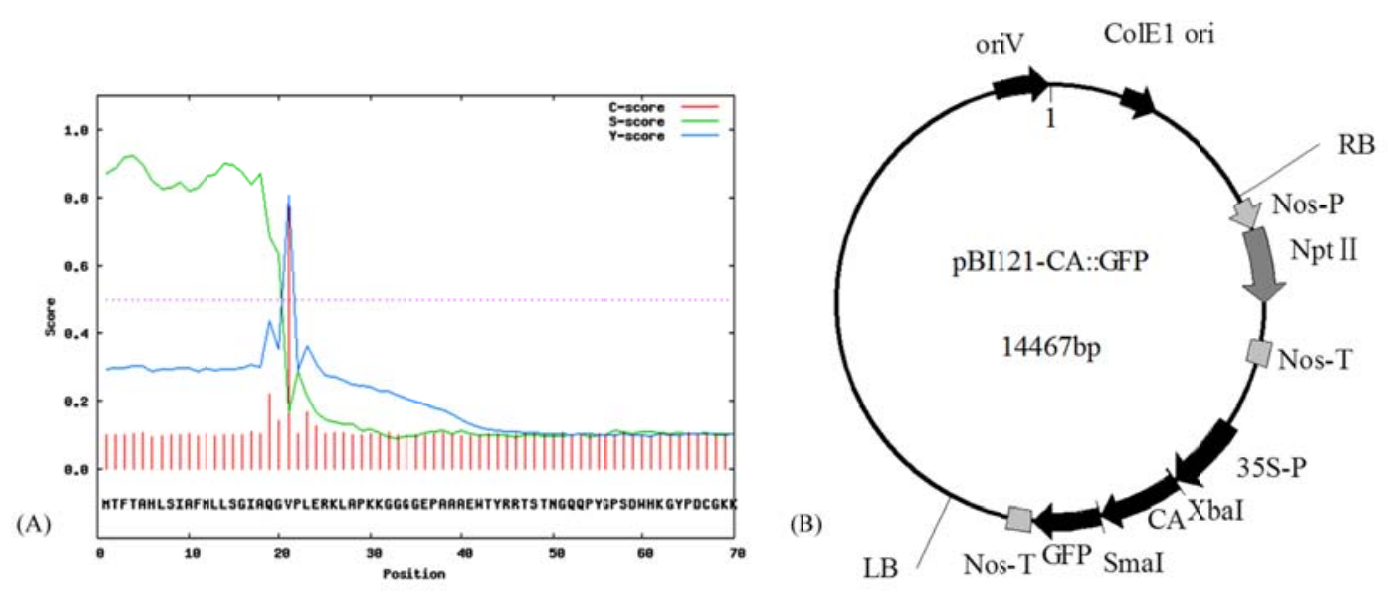

Figure 2. Signal-proteins prediction and the construction of fluorescence fusion expression vector of $C A$ gene. (A) The prediction results of signal-proteins of $C A$ gene. (B) The construction of fluorescence fusion expression vector of $C A$ gene with pBI121-GFP.

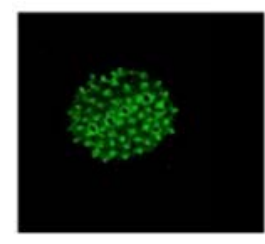

a

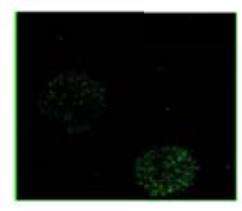

$\mathbf{A 1}$

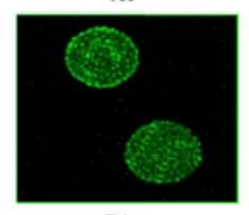

B1

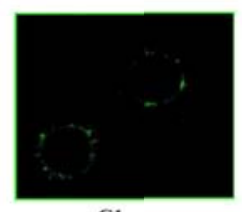

C1

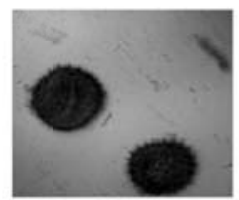

A2

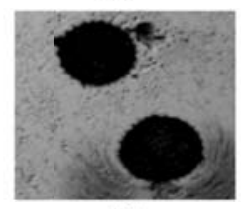

B2

Y-2067 pollen

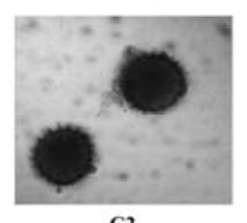

C2

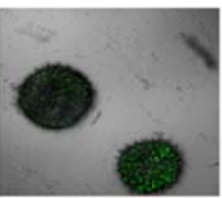

A.3

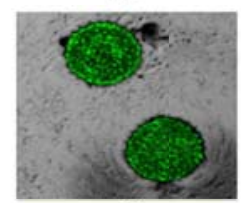

B3

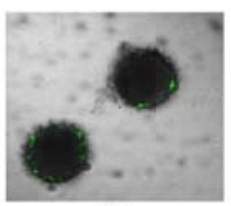

C3

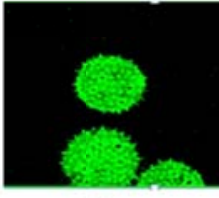

D1

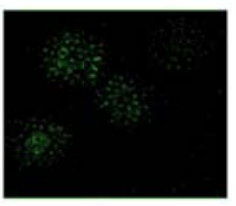

E1

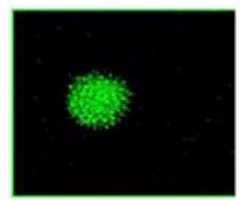

F1

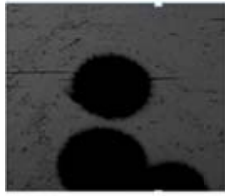

D2

ZA-23 pollen

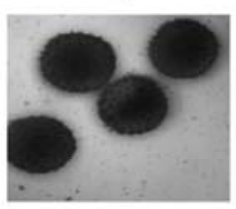

E2

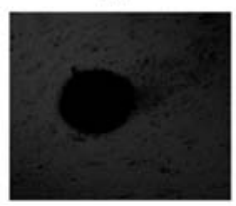

F2

GZ-2 pollen

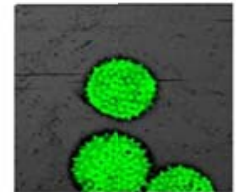

D3

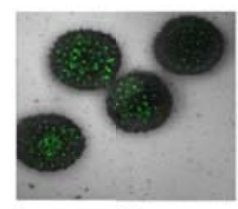

E3

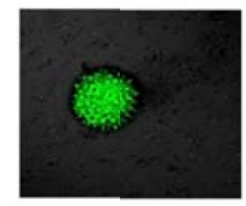

F3

(B)

Figure 3. Spontaneous green fluorescent of cotton pollen and transient expression analysis of $C A$ gene by gene gun transformation in cotton pollen (wavelength: $488 \mathrm{~nm}$ ). (A) Green fluorescent spontaneously of cotton pollen. a) H-109; b) H-177; c) ZA-23. (B) Transient expression of $C A$ in cotton. A1, B1, C1, D1, E1, F1: Fluorescence images; A2, B2, C2, D2, E2, F2: Bright-field pollen grain images; A3, B3, C3, D3, E3, F3: Merged images of A1 and A2, B1 and B2, C1 and C2, $\mathrm{D} 1$ and $\mathrm{D} 2, \mathrm{E} 1$ and $\mathrm{E} 2, \mathrm{~F} 1$ and F2, respectively. 


\subsection{Detection of green auto-fluorescence emission of the cotton pollen}

The clone of the salt-tolerance gene $C A$ and the construction of the green fluorescent protein (GFP) fusion expression vector were accomplished in preliminary work. The results indicated that green auto-fluorescence interference existed in every cotton varieties. Until now, there have been no reports establishing whether the pollen emitted green auto-fluorescence. Therefore, in our study, we tried to verify whether the green auto-fluorescence of the pollen existed, and whether different pollens had different green fluorescence intensities. So we selected cotton varieties with weak green fluorescence to verify the expression level of the foreign gene $C A$ of Saccharina japonica in the cotton pollens.

Table 1. Materials and the results

\begin{tabular}{|c|c|}
\hline Varieties & Spontaneous fluorescence intensity of Pollen \\
\hline Z-07 & strong \\
\hline Z-12 & strong \\
\hline Z-41 & strong \\
\hline Z-221 & strong \\
\hline Z-9409 & strong \\
\hline Z-9806 & strong \\
\hline H-109 & strong \\
\hline H-177 & strong \\
\hline BPA-68 & strong \\
\hline TM-1 & strong \\
\hline GK-50 & strong \\
\hline GK-19 & strong \\
\hline$X-2$ & strong \\
\hline L-1138 & strong \\
\hline HU-749513 & strong \\
\hline NG-1 & strong \\
\hline NG-2 & strong \\
\hline KHW-164 & strong \\
\hline Z-701 & strong \\
\hline Z-710 & strong \\
\hline ZNG-191 & strong \\
\hline ZNG-192 & strong \\
\hline ZA-16 & strong \\
\hline Y-2067* & weak \\
\hline ZA-23 & weak \\
\hline GZ-2 & weak \\
\hline
\end{tabular}

Note. *Y-2067 was used as a control to categorize the fluorescence intensities. Cotton varieties with stronger fluorescence intensities than Y-2067 were termed as strong and others were weak.

We observed the green auto-fluorescence of 26 cotton pollens by FV1000 at a wavelength of $488 \mathrm{~nm}$. The results indicated that all of the pollens had a different degree of green auto-fluorescence. Table 1 summarizes the different fluorescence intensities. For example, H-109 (see Figure 3A-a) and H-177 (see Figure 3A-b) were representative materials with strong auto-fluorescence. By contrast, ZA-23 was a typical material with weak green auto-fluorescence (see Figure 3A-c). Among them, Y-2067, ZA-23, and GZ-2, which were three upland cotton materials, had weaker green auto-fluorescence. Hence, we chose the pollens of Y-2067, ZA-23, and GZ-2 for pBI121-CA::GFP conversion to investigate the transient expression. The remaining 23 materials with strong auto-fluorescence were no longer used.

\subsection{Transient expression of CA gene in cotton pollen analysis}

We performed particle bombardment of cotton pollens with gold powder and plasmid suspension. Then we observed them via confocal laser scanning microscopy (see Figure 3B) after overnight culture at room temperature. We found that green 
auto-fluorescence intensities of all of the three pollens were enhanced, meaning the gene expression was successful and the foundation was laid for the development of salt-tolerant materials via particle bombardment of cotton pollens. The results indicated that Y-2067, ZA-23, and GZ-2 normally had weaker green auto-fluorescence (A1, A2, A3; C1, C2, C3; E1, E2, and E3). However, after the particle bombardment, the green auto-fluorescence was enhanced obviously (B1, B2, $\mathrm{B} 3$; D1, D2, D3; F1, F2, and F3), revealing that the expression of $C A$ gene in the pollens was successful, and the gene particle bombardment is a practicable and reliable method.

\subsection{Gene gun living conversion of CA gene in cotton}

Gene living conversion in plants has become a hotspot these years. In this study, Bt cotton varieties, Hu749513 and F12, and non-Bt cotton varieties, GK50 and $\mathrm{Yu}$ 2067, were selected to conduct the gene gun (GDS-80) living conversion of $C A$ gene in the fields. The vector pBI121-CA mixed with gold powder was suspended in absolute ethyl alcohol. The cotton flowers of the selected varieties were harvested on the previous day and kept on a super clean experimental table at room temperature. Cotton pollens were collected from the flowers, harvested into sterile petri dishes, and bombarded by the portable gene gun GDS-80 containing $10 \mu \mathrm{l}$ vector mixture. Then, the bombarded pollen was used to pollinate other flowers, which were subsequently marked (see Figure 4A). When the seeds matured, we harvested the transgenic seeds and performed a molecular analysis.

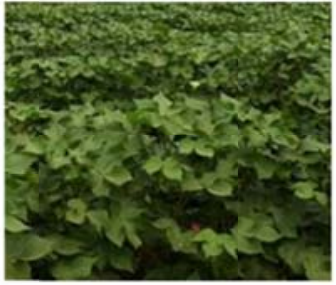

a

(A)

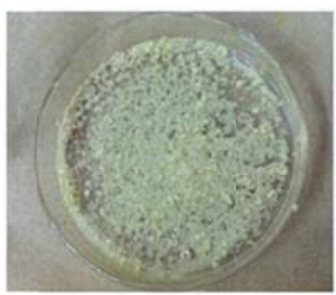

d

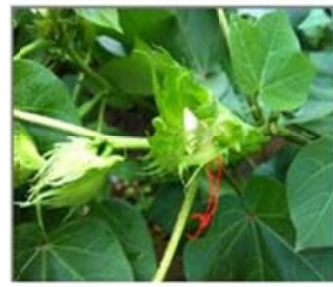

b

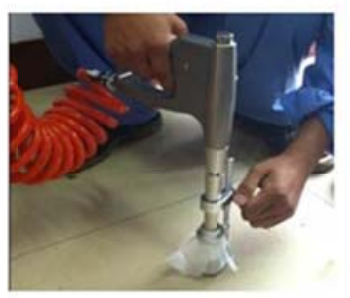

$\mathrm{e}$

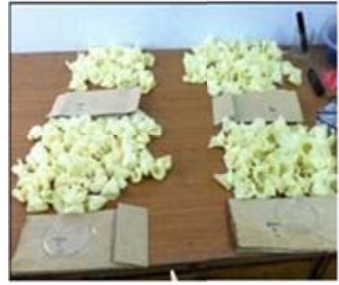

c

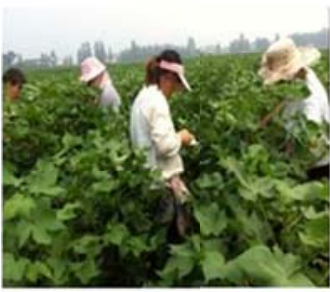

f

(B)

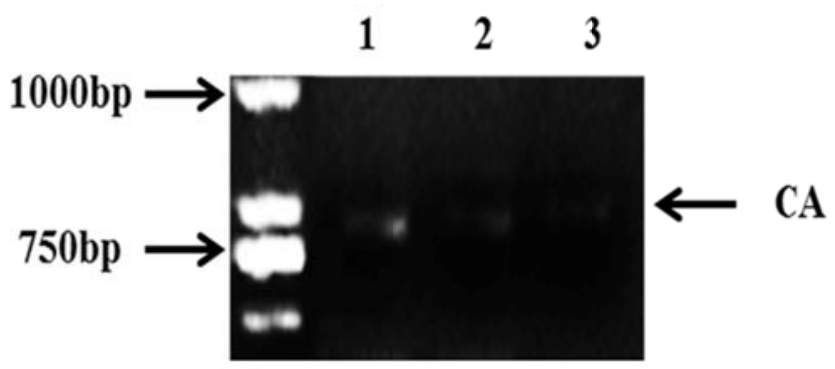

Figure 4. The flow chart of gene gun transformation in the field and molecular detection result of transgenic cotton plants. (A) The flow chart of gene gun transformation in the field. a) the cotton in the field; b) getting rid of stamens, putting on the candle tube and marking the flowers; c) the flowers collected; d) the pollen collected; e) gene gun bombardment; f) pollination. (B) Molecular detection result of the $C A$ gene. 


\subsection{Salt tolerance detection of T1 seeds of transgenic cotton}

We obtained $162 \mathrm{~T} 1$ seeds after the $C A$ gene conversion into non-insect-resistant cotton (Hu 749513) and compared them with the non-transgenic seeds of $\mathrm{Hu} 749513$. We took 40 full and uniform seeds and subjected them to the sandwich filter paper cultivation method. After the treatment with $0.8 \% \mathrm{NaCl}$ solution, the seeds were cultivated and left to germinate in an illumination incubator with intervals of $14 \mathrm{~h}$ in the light at $28^{\circ} \mathrm{C}$ and $10 \mathrm{~h}$ in the dark at $25^{\circ} \mathrm{C}$. The process was repeated three times, and the germination data were calculated. As shown in Table 2, the transgenic seeds had higher salt-tolerance ability during germination than those in the control group, meaning that the $C A$ gene improved the salt tolerance of seeds.

Table 2. Transgenic salt resistance testing

\begin{tabular}{llll}
\hline Materials & Seeds in total & Number of shoots & Germination rate (\%) \\
\hline Transgenic seeds of $C A$ gene & 120 & $27^{* *}$ & 22.5 \\
Control & 120 & 1 & 0.08 \\
\hline
\end{tabular}

We planted the germinated seeds in a greenhouse and performed DNA detection assays in young leaves. Aiming at the identification of the $C A$ gene, we designed primers (F: ATGACTTTCACGGCGCACCTATC; R: TTAGTAGTGGA CGAAGAA GATC) and detected the salt tolerance gene, which confirmed the successful transgenosis (see Figure 4B).

\section{Discussions}

The response of plants to salt stress is controlled by complicated polygenes, involving many physiological, biochemical, and cellular changes, as well as protective, defensive, and salt tolerance-related gene expression. Extensive research on salt-tolerance genes has been conducted in the world. Under the condition of salt stress, plant genes are selectively expressed in order to improve the resistance ability. The studies on salt-tolerant genes would improve the knowledge and understanding of the underlying mechanisms of action and, by their contribution to discovering substantial theoretical evidence, they will facilitate the realization of further transgenic research ${ }^{[27,28]}$.

$\alpha-, \beta-$, and $\gamma-C A$ have been reported to be distributed widely in microalgae and higher plants, are zinc-metalloenzymes that catalyze the reversible interconversion of $\mathrm{CO}_{2}$ and $\mathrm{HCO}_{3}{ }^{-}{ }^{[29]}$. In higher plants, $C A$ s play a vital role in the process of photosynthesis, respiration, ion absorption ${ }^{[30]}$. In the study, germination capacity of $\mathrm{T} 1$ transgenic seeds increased, which may be because that $C A$ gene enhanced the respiration of transgenic respiration. The enzyme activity of $C A$ is kind of photosynthetic carbon metabolism enzyme in adapting stress conditions and could be induced by the substrate, playing an important function in keeping stable photosynthetic carbon metabolism ${ }^{[31]}$. Previous studies showed that AtaCA1 protein may be transported into chloroplast through the secretory pathway ${ }^{[32]}$ and $\beta$-CA6 was located in mitochondria ${ }^{[33]}$. This suggested that different $C A$ s have different locations, which may lead to different functions.

Nowadays, there are a large number of reports concerning genetically modified (gm) events. GhMAPK is the first $M A P K$ gene cloned in Gossypium hirsutum, which plays an important role in salt stress response. Yamada et al. cloned the salt-tolerant gene mangrin from Bruguiera sexangula (Lour.) Poir. and converted it in Escherichia coli, yeasts, and tobacco, improving the salt tolerance of the obtained transformant ${ }^{[34]}$. Yu et al. converted the salt-tolerant gene mangrin into Eucalyptus and also acquired a transformant with enhanced salt tolerance ${ }^{[35]}$. Gao et al. obtained wheat plants with higher salt and drought tolerance by GmDREB gene transgenosis ${ }^{[36]}$. Lee et al. converted TPS gene of Escherichia coli into tobacco to improve its salt tolerance ${ }^{[37]}$. Besides, Ganesan et al. isolated the AmMYB1 gene from grey mangrove and incorporated it into tobacco to acquire high-salt-tolerant plants ${ }^{[38]}$. Russell et al. bombarded bean stem tips with exogenous DNA covered with Tungsten particles and obtained transgenic plants ${ }^{[38]}$. Nowadays, there are few reports about foreign gene insertion into cotton. El-Shemy et al. transferred the V3-1 gene into soybean, which increased the content of globulin and improved its nutritional quality ${ }^{[40]}$. Jun Wu et al. developed a modified particle bombardment method for plant transgenesis integrating foreign DNA into the plant genome with an increased transformation frequency, as compared to the conventional particle bombardment method ${ }^{[41]}$. The research on the related endogenous gene of salt 
tolerance from cotton is emerging. Some genes, including GhAKT1 and GhWRKY3, were cloned and inserted into onion for transient expression studies ${ }^{[42,43]}$, while similar research in cotton has not been reported. The germination ability of $C A$ transgenic seeds under salt stress is improved, which leads to the conclusion that $C A$ is a plant salt-tolerance gene. In recent years, the inclusion of foreign genes into tobacco, tomato, wheat, rice, corn, soybean, and cotton has been studied extensively ${ }^{[44-50]}$. The transgenic plants were mainly acquired by Agrobacterium tumefaciens-mediated transformation and bombardment of embryo or callus via a desktop gene gun. In the process of Agrobacterium-mediated in planta transformation, the genotype is generally found to influence T-DNA transfer and transgene expression in Arabidopsis and grapevine ${ }^{[51-54]}$. Studies have reported in other plants species, the choice of the Agrobacterium strain appeared critical and specific because of specific host-bacteria inactions ${ }^{[52,55]}$. In our work, we cloned a exogenous gene $C A$ from Saccharina japonica, which was an extreme salt-tolerant algae, enlarging our range of experiment materials.

In our investigation, firstly, we have obtained 3 cotton varieties with weak green fluorescent spontaneously from many upland cottons and particle bombardment in vivo was applied for the transformation of cotton pollens. Second, we established a system of transient expression of cotton pollens via the particle bombardment technology, which is characterized by easier manipulation, lower pollution, and higher survival rates compared with the pollen tube injection, and provided theoretical evidence and technical support for new methods of transgenosis and creation of salt-tolerant materials.

\section{Acknowledgments}

This work was supported by grants from The China Major Projects for Genetically modified organisms breeding (Grant No. 2014ZX0800504B). We also appreciate the reviewers and editors for their patience to the work.

\section{Conflict of interest}

Wuwei Ye, Jingjing Kong and Xuke Lu conceived and designed the research. Jingjing Kong and Xuke Lu conducted the experiments. Xiaojie Zhao, Zujun Yin, and Shuai Wang analyzed the data. Jingjing Kong and Xuke Lu wrote the manuscript. Delong Wang, Junjuan Wang and Weili Fan edited the manuscript. Jingjing Kong and Xuke Lu contributed equally to this work. All of the authors declare that there is no conflict of interest.

\section{References}

[1] Zhao XJ, Lu XK, Yin ZJ, et al. Genome-wide Identification and Structural Analysis of Pyrophosphatase Gene Family in Cotton. Crop Sci. 2016; 56: 1-10. http://dx.doi.org/10.2135/cropsci2014.12.0832

[2] Yoshida K. Plant biotechnology-Genetic engineering to enhance plant salt tolerance. Journal of Bioscience and Bioengineering. 2002; 94: 585-90. http://dx.doi.org/10.1016/S1389-1723(02)80199-2

[3] Wang WX, Vinocur B, Altman A. Plant responses to drought, salinity and extreme temperatures: towards genetic engineering for stress tolerance. Planta. 2003; 218: 1-14. PMid:14513379. http://dx.doi.org/10.1007/s00425-003-1105-5

[4] Chavez L, Gonzalez LM. Moleculars mechanisms in plant salt tolerance. Itea-Informacion Tecnica Economica Agraria. 2009; 105: 231-56.

[5] Deinlein U, Stephan AB, Horie T, et al. Schroeder. Plant salt-tolerance mechanisms. Trends Plant Sci. 2004; $19: 371-9$. PMid:24630845. http://dx.doi.org/10.1016/j.tplants.2014.02.001

[6] Hassan MI, Shajee B, Waheed A, et al. Structure, function and applications of carbonic anhydrase isozymes. Bioorganic \& Medicinal Chemistry. 2013; 21: 1570-82. PMid:22607884. http://dx.doi.org/10.1016/j.bmc.2012.04.044

[7] Yadav RR, Krishnamurthi K, Mudliar SN, et al. Carbonic anhydrase mediated carbon dioxide sequestration: Promises, challenges and future prospects. J Basic Microbiol. 2014; 54: 472-81. PMid:24740638. http://dx.doi.org/10.1002/jobm.201300849

[8] Smith EC, Griffiths H. The role of carbonic anhydrase in photosynthesis and the activity of the carbon- concentrating-mechanism in bryophytes of the class Anthocerotae. New Phytologist. 2000; 145: 29-37. http://dx.doi.org/10.1046/j.1469-8137.2000.00559.x

[9] Tiwari A, Kumar P, Singh S, et al. Carbonic anhydrase in relation to higher plants. Photosynthetica. 2005; 43: 1-11. http://dx.doi.org/10.1007/s11099-005-1011-0

Published by Sciedu Press 
[10] Gilmour KM. Perspectives on carbonic anhydrase. Comparative Biochemistry and Physiology a-Molecular \& Integrative Physiology. 2010; 157: 193-7. PMid:20541618. http://dx.doi.org/10.1016/j.cbpa.2010.06.161

[11] ProtoschillKrebs G, Wilhelm C, Kesselmeier J. Consumption of carbonyl sulphide (COS) by higher plant carbonic anhydrase (CA). Atmospheric Environment. 1996; 30: 3151-6. http://dx.doi.org/10.1016/1352-2310(96)00026-X

[12] Bascik-Remisiewicz A, Tukaj Z. The role of carbonic anhydrase (CA) in cadmium toxicity to green alga Scenedesmus armatus. Acta Physiologiae Plantarum. 2005; 27: 17-8.

[13] Vullo D, De Luca V, Scozzafava A, et al. The first activation study of a bacterial carbonic anhydrase (CA). The thermostable alpha-CA from Sulfurihydrogenibium yellowstonense YO3AOP1 is highly activated by amino acids and amines. Bioorganic \& Medicinal Chemistry Letters. 2012; 22: 6324-7. PMid:22999416. http://dx.doi.org/10.1016/j.bmcl.2012.08.088

[14] Raven JA. Phycological Reviews 15. Photosynthetic and Nonphotosynthetic Roles of Carbonic-Anhydrase in Algae and Cyanobacteria. Phycologia. 1995; 34: 93-101. http://dx.doi.org/10.2216/i0031-8884-34-2-93.1

[15] Tripp BC, Smith K, Ferry JG. Carbonic anhydrase: New insights for an ancient enzyme. Journal of Biological Chemistry. 2001; 276: 48615-8. PMid:11696553. http://dx.doi.org/10.1074/jbc.R100045200

[16] Ye RX, Yu Z, Shi WW, et al. Characterization of \&alpha type carbonic anhydrase (CA) gene and subcellular localization of \&alpha A in the gametophytes of Saccharina japonica. Journal of Applied Phycology. 2014: 26: 881-90. http://dx.doi.org/10.1007/s10811-013-0221-2

[17] Kim K, Portis AR. Temperature dependence of photosynthesis in Arabidopsis plants with modifications in Rubisco activase and membrane fluidity. Plant and Cell Physiology. 2005; 46: 522-30. PMid:15695447. http://dx.doi.org/10.1093/pcp/pci052

[18] Peterson RL, Shelp B. $\mathrm{CO}_{2}$-concentrating mechanisms in photoautotrophic microorganisms - The 5th International Symposium on Inorganic Carbon Utilization by Aquatic Photosynthetic Organisms - Saint-Sauveur, Quebec, Canada, 24-28 August 2004. Canadian Journal of Botany-Revue Canadienne De Botanique. 2005; 83: V.

[19] Miao XL, Zhang YJ, Xia XC, et al. Mapping quantitative trait loci for pre-harvest sprouting resistance in white-grained winter wheat line CA 0431. Crop \& Pasture Science. 2013; 64: 573-9. http://dx.doi.org/10.1071/CP13102

[20] Yu S, Zhang XX, Guan QJ, et al. Expression of a carbonic anhydrase gene is induced by environmental stresses in Rice (Oryza sativa L.). Biotechnology Letters. 2007; 29: 89-94. PMid:17016673. http://dx.doi.org/10.1007/s10529-006-9199-z

[21] Fisher M, Gokhman I, Pick U, et al. A salt-resistant plasma membrane carbonic anhydrase is induced by salt in Dunaliella salina. Journal of Biological Chemistry. 1996; 271: 17718-23. PMid:8663366. http://dx.doi.org/10.1074/jbc.271.30.17718

[22] Waksman G. Structural and molecular biology of bacterial type IV secretion systems. Febs Journal. 2015; $282: 381$.

[23] Narasimhulu SB, Deng X, Sarria R, et al. Early transcription of Agrobacterium T-DNA genes in tobacco and maize. Plant Cell. 1996; 8: 873-86. PMid:8672885. http://dx.doi.org/10.1105/tpc.8.5.873

[24] Clough SJ, Bent AF. Floral dip: a simplified method for Agrobacterium-mediated transformation of Arabidopsis thaliana. Plant Journal. 1998; 16: 735-43. http://dx.doi.org/10.1046/j.1365-313x.1998.00343.x

[25] Brencic A, Angert ER, Winans SC. Unwounded plants elicit Agrobacterium vir gene induction and T-DNA transfer: transformed plant cells produce opines yet are tumour free. Mol Microbiol. 2005; 57: 1522-31. PMid:16135221. http://dx.doi.org/10.1111/j.1365-2958.2005.04763.x

[26] Bodas K, Brennig C, Diller KR, et al. Cryopreservation of Blue-Green and Eukaryotic Algae in the Culture Collection at the University-of-Texas at Austin. Cryo-Letters. 1995; 16: 267-74.

[27] Yamaguchi-Shinozaki K, Shinozaki K. Improving plant drought, salt and freezing tolerance by gene transfer of a single stress-inducible transcription factor. Rice Biotechnology: Improving Yield, Stress Tolerance and Grain Quality. 2001; 236: 176-89.

[28] Vinocur B, Altman A. Recent advances in engineering plant tolerance to abiotic stress: achievements and limitations. Current Opinion in Biotechnology. 2005; 16: 123-32. PMid:15831376. http://dx.doi.org/10.1016/j.copbio.2005.02.001

[29] Moroney JV, Ma YB, Frey WD, et al. The carbonic anhydrase isoforms of Chlamydomonas reinhardtii: intracellular location, expression, and physiological roles. Photosynthesis Research. 2011; 109: 133-49. PMid:21365258. http://dx.doi.org/10.1007/s11120-011-9635-3

[30] Supuran CT. Carbonic Anhydrase Inhibitors: Possible Anticancer Drugs With a Novel Mechanism of Action. Drug Development Research. 2008; 69: 297-303. http://dx.doi.org/10.1002/ddr.20262

[31] Ludwig M. Carbonic anhydrase and the molecular evolution of C-4 photosynthesis. Plant Cell and Environment. 2012 ; $35: 22-37$. PMid:21631531. http://dx.doi.org/10.1111/j.1365-3040.2011.02364.x 
[32] Villarejo A, Buren S, Larsson S, et al. Evidence for a protein transported through the secretory pathway en route to the higher plant chloroplast. Nature Cell Biology. 2005; 7: 1224-31. PMid:16284624. http://dx.doi.org/10.1038/ncb1330

[33] Ferreira FJ, Guo C, Coleman JR. Reduction of plastid-localized carbonic anhydrase activity results in reduced Arabidopsis seedling survivorship. Plant Physiology. 2008; 147: 585-94. PMid:18434607. http://dx.doi.org/10.1104/pp.108.118661

[34] Yamada A, Saitoh T, Mimura T, et al. Expression of mangrove allene oxide cyclase enhances salt tolerance in Escherichia coli, yeast, and tobacco cells. Plant and Cell Physiology. 2002; 43: 903-10. PMid:12198193. http://dx.doi.org/10.1093/pcp/pcf108

[35] Yu X, Kikuchi A, Shimazaki T, et al. Assessment of the salt tolerance and environmental biosafety of Eucalyptus camaldulensis harboring a mangrin transgene. Journal of Plant Research. 2013; 126: 141-50. PMid:22752709.

http://dx.doi.org/10.1007/s10265-012-0503-9

[36] Gao SQ, Xu HJ, Cheng XG, et al. Improvement of wheat drought and salt tolerance by expression of a stress-inducible transcription factor GmDREB of soybean (Glycine max). Chinese Science Bulletin. 2005; 50: 2714-23. http://dx.doi.org/10.1360/982005-1234

[37] Lee DH, Ryu H, Bae HH, et al. Transgenic Tobacco Plants harboring the Trehalose Phosphate Synthase TPS gene of Escherichia coli increased Tolerance to Drought Stress. Research Journal of Biotechnology. 2012; 7: 22-6.

[38] Ganesan G, Sankararamasubramanian HM, Harikrishnan M, et al. A MYB transcription factor from the grey mangrove is induced by stress and confers $\mathrm{NaCl}$ tolerance in tobacco (2012; 63: 4549). Journal of Experimental Botany. 2013; $64: 1782$.

[39] Russell DR, Wallace KM, Bathe JH, et al. Stable transformation of Phaseolus vulgaris via electric-discharge mediated particle acceleration. Plant Cell Reports. 1993; 12: 165-9. PMid:24196855. http://dx.doi.org/10.1007/BF00239099

[40] 2002 Congress on In Vitro Biology and 10th IAPTC\&B (International Association for Plant Tissue Culture and Biotechnology) Congress, June 25-29, 2002. Orlando, Florida, USA. Abstracts. In Vitro Cell Dev Biol Anim. 2002; 38: 1A-152A. PMid: 12108418.

[41] Wu J, Du H, Liao X, et al. An improved particle bombardment for the generation of transgenic plants by direct immobilization of relleasable Tn5 transposases onto gold particles. Plant Mol Biol. 2011; 77: 117-27. PMid:21643845. http://dx.doi.org/10.1007/s11103-011-9798-5

[42] Guo RY, Yu FF, Gao Z, et al. GhWRKY3, a novel cotton (Gossypium hirsutum L.) WRKY gene, is involved in diverse stress responses. Mol Biol Rep. 2011; 38: 49-58. PMid:20238169. http://dx.doi.org/10.1007/s11033-010-0076-4

[43] Xu J, Tian XL, Eneji AE, et al. Functional characterization of GhAKT1, a novel Shaker-like K+ channel gene involved in K+ uptake from cotton (Gossypium hirsutum). Gene. 2014; 545: 61-71. PMid:24802116. http://dx.doi.org/10.1016/j.gene.2014.05.006

[44] Li R, Zhang ZM, Zhang QF. Transformation of japonica rice with RHL gene and salt tolerance of the transgenic rice plant. Chinese Science Bulletin. 2002; 47: 998-1002.

[45] Liu XH, Tan ZB, Li WC, et al. Cloning and transformation of SCMV CP gene and regeneration of transgenic maize plants showing resistance to SCMV strain MDB. African Journal of Biotechnology. 2009; 8: 3747-53.

[46] Lv SL, Lian LJ, Tao PL, et al. Overexpression of Thellungiella halophila H+-PPase (TsVP) in cotton enhances drought stress resistance of plants. Planta. 2009; 229: 899-910. PMid:19130078. http://dx.doi.org/10.1007/s00425-008-0880-4

[47] Liu X, Jin W, Liu J, et al. Transformation of wheat with the HMW-GS 1Bx14 gene without markers. Russian Journal of Genetics. 2011; 47: 182-8. http://dx.doi.org/10.1134/S1022795411010066

[48] Liu Y, Yu L, Fu YL, et al. Transformation of ALO Gene Mediated by Agrobacterium Tumefaciens in Soybean Using Hypocotyl Explants and Partial Incubation Method. International Conference on Biological, Medical and Chemical Engineering. 2013: 263-9.

[49] Arshad W, Haq IU, Waheed MT, et al. Agrobacterium-Mediated Transformation of Tomato with rolB Gene Results in Enhancement of Fruit Quality and Foliar Resistance against Fungal Pathogens. Plos One. 2014: 9. http://dx.doi.org/10.1371/journal.pone.0096979

[50] Quintanilha DM, De Jesus EM, Van Sluys M. Preliminary Results on Tobacco Transcriptome Changes Induced by Agrobacterium tumefaciens-mediated Transformation with the Hygromycin Resistance Gene hpt. In Vitro Cellular \& Developmental Biology-Plant. 2013; 49: 483-4.

[51] Chabaud M, de Carvalho-Niebel F, Barker DG. Efficient transformation of Medicago truncatula cv. Jemalong using the hypervirulent Agrobacterium tumefaciens strain AGL1. Plant Cell Reports. 2003; 22: 46-51. PMid:12827434. http://dx.doi.org/10.1007/s00299-003-0649-y 
[52] Wroblewski T, Tomczak A, Michelmore R. Optimization of Agrobacterium-mediated transient assays of gene expression in lettuce, tomato and Arabidopsis. Plant Biotechnology Journal. 2005; 3: 259-73. PMid:17173625. http://dx.doi.org/10.1111/j.1467-7652.2005.00123.x

[53] Santos-Rosa M, Poutaraud A, Merdinoglu D, et al. Development of a transient expression system in grapevine via agro-infiltration. Plant Cell Reports. 2008; 27: 1053-63. PMid:18317773. http://dx.doi.org/10.1007/s00299-008-0531-z

[54] Zottini M, Barizza E, Costa A, et al. Agroinfiltration of grapevine leaves for fast transient assays of gene expression and for long-term production of stable transformed cells. Plant Cell Reports. 2008; 27: 845-53. PMid:18256839. http://dx.doi.org/10.1007/s00299-008-0510-4

[55] Tzfira T, Citovsky V. Partners-in-infection: host proteins involved in the transformation of plant cells by Agrobacterium. Trends Cell Biol. 2002; 12: 121-9. http://dx.doi.org/10.1016/S0962-8924(01)02229-2 